\title{
In Vitro Production of Embryos: Principles, Techniques and Applications
}

\author{
Ahmed Abdel Gadir Adam \\ Taif University, College of Art and Science in Raniah
}

\begin{abstract}
This review aimed to give a brief account on the principles, techniques and applications for in vitro production (IVP) of embryos and related biotechnologies. IVP of embryos provides an excellent source of low cost embryos for basic research on developmental biology and physiology and for the application of emerging biotechnologies such as nuclear transfer, production of transgenic animals, embryonic stem cells (ESCs), intracytoplasmic sperm injection (ICSI) embryo splitting, parthenogenetic activation and generation of interspecies chimeras. The successful development and application of IVP of embryos and related technologies depend on a whole range of basic protocols including in vitro maturation (IVM), in vitro fertilization (conventional IVF, parthenogenetic or ICSI) and in vitro culture (IVC) of fertilized oocytes. Advances in these techniques during the last decades have been rapid and impressive and culture media play a major role in this success. Recent advances in stem cells and gene engineering have paved the way for the generation of human induced Embryonic Stem Cells (iESCs) essential for creation of xenotransplants. Generation of human Pluripotent Embryonic Stem Cells (hPESCs), from parthenogenetic activation of human infertility treatments, gained new interest as ethical circumvent to create embryos for research in regenerative and therapeutic medicine.
\end{abstract}

Keywords: biotechnology, chimera, embryo splitting, ESCs, parthenogenesis

\section{INTRODUCTION}

In vitro production (IVP) of embryos provides an excellent source of low cost embryos for basic research on developmental biology and physiology, and for the application of emerging biotechnologies such as nuclear transfer, production of transgenic animals and stem cell research. The successful development and application of IVP of embryos and related biotechnologies depend on a whole range of basic protocols including in vitro maturation (IVM), in vitro fertilization (IVF) of oocytes and in vitro culture (IVC) of fertilized oocytes. Current methods for IVP of embryos are dependent upon the supply of oocytes from large antral follicles, which are present in the ovary in a relatively small number. Superovulation is used to increase the harvest of matured oocytes from the ovaries; but, this technique cannot stimulates the tremendous amount of preantral follicles that are irresponsible to the hormonal treatment. So, culture of preantral follicles for in vitro growth (IVG) has the potential not only to produce large and homogenous quantities of oocytes for IVP but also to study the physiological process of growth and ovulation.

Until the 1980s embryologists made their media in house with limited quality control [1]. However, research during the last thirty years has resulted in the development of more physiological and effective culture media capable of maintaining the viability of the developing embryo. Nowadays, there are numerous commercially available culture media contain up to eighty components including nutrients, vitamins and growth factors [2]. The commercialization of culture media has created competition, has increased the standards and has brought into clinical practice a variety of options. In contrast to media produced in house, there are now strict manufacturing and quality assessment requirements, improved batch-to-batch consistency and less contamination [2].

Recent advances in stem cells and gene engineering have paved the way for the generation of induced pluripotent Embryonic Stem Cells, iESCs. These cells are produced from reprogramming of adult cells and can be derived from patients with a genetic disease to model the disease in vitro and create xenotransplants. The generation of human Pluripotent Embryonic Stem Cells, hPECSs from parthenogenetic activation of human infertility treatment, gained new interest as ethical circumvent to create embryos for research in areas such as regenerative and therapeutic medicine. This review will 
describe briefly the principles and application of in vitro production of embryos and their related biotechnologies such as stem cell research, intracytoplasmic sperm injection, embryo splitting, and parthenogenetic activation of oocytes and creation of interspecies chimera.

\section{IN VITRO CULTURE MEDIA}

The culture media is nothing but a mimic to the chemical composition of the physiological fluid in the reproductive tract. From the first tissue culture medium based on blood serum that was developed in University College London and was able to support in vitro a beating frog heart [3] we have reached an era where culture media contain up to eighty components including nutrients, vitamins and growth factors [2]. Until the 1980s the culture media were made in house, with limited quality control. Nowadays, there are eight major companies whose culture media are used in the majority of studies. The list includes Cook Medical, Cooper Surgical that produces both SAGE and ORIGIO media, FertiPro, Gynemed, and Gynotec. The commercialization of culture media has created competition, has increased the standards and has brought into clinical practice a variety of options. In contrast to media produced in house, there are now strict manufacturing and quality assessment requirements, improved batch-to-batch consistency and less contamination [2].

\subsection{Formulation of Culture Media in House}

Culture media can be formulated in the laboratory as demonstrated by the Potassium Simplex Optimization Methods, KSOM [4]. The components of this medium are as follows: $95.0 \mathrm{mM}$ of $\mathrm{NaCl}$, $2.50 \mathrm{mM}$ of $\mathrm{KCl}, 1.71 \mathrm{mM}$ of $\mathrm{CaCl}_{2} .2 \mathrm{H}_{2} \mathrm{O}, 0.35 \mathrm{mM}$ of $\mathrm{KH}_{2} \mathrm{PO}_{4}, 0.2 \mathrm{mM}$ of $\mathrm{MgSO}_{4} .7 \mathrm{H}_{2} \mathrm{O}, 25.00$ $\mathrm{mM}$ of $\mathrm{NaHCO}_{3}, 0.2 \mathrm{mM}$ of Na pyruvate, $10.0 \mathrm{mM}$ of Na lactate $0.2 \mathrm{mM}$ of Glucose, $1 \mathrm{mM}$ of glutamine and $0.1 \mathrm{mM}$ of EDTA. In addition the medium is supplemented with $4 \mathrm{mg} / \mathrm{ml} \mathrm{BSA}, 60$ $\mathrm{mg} / \mathrm{ml}$ penicillin and $50 \mathrm{mg} / \mathrm{ml}$ streptomycin. To formulate such medium in house, the amount from each ingredient is calculated by multiplying the concentration in $\mathrm{mM}$ with the molecular weight (Table 1). Because the chemical amounts are minute, two stock solutions are composed. Stock A is alkaline and stock B is acidic (Table 2 and 3, respectively). Few drops of phenol red added to each of stock $\mathrm{A}$ and $\mathrm{B}$ in order to monitor changes in the $\mathrm{pH}$. With the alkaline solution the phenol red gives a pinkish tints and with the acidic it is bluish. The two stock solutions can be kept at room temperature and used for one month. The working medium is formulated by mixing $10 \mathrm{ml}$ from stock A and 16.2 $\mathrm{ml}$ from stock B (Table 4). To this solution $2.2 \mathrm{mg}$ of pyruvate, $3.6 \mathrm{mg}$ of glucose, $142.6 \mu \mathrm{l}$ of Sodium Lactate ( $60 \%$ solution density $1.31 \mathrm{~g} / \mathrm{ml}), 14.6 \mathrm{mg}$ of glutamine, $3.72 \mathrm{mg}$ of EDTA, $50 \mathrm{mg} / \mathrm{ml}$ of Gentamycin, $60 \mathrm{mg} / \mathrm{ml}$ Penicillin and $4 \mathrm{mg} / \mathrm{ml}$ of BSA added. Finally, the solution is completed to $100 \mathrm{ml}$ with distilled water, filtered, kept at $4^{\circ} \mathrm{C}$ and used for one week.

Table1. Potassium Simplex Optimization MethodsMedium, KSOM [4]

\begin{tabular}{|l|l|l|l|l|}
\hline component & $\mathbf{m M}$ & $\mathbf{F W}$ & $\mathbf{m g} / \mathbf{L}$ & $\mathbf{g} / \mathbf{L}$ \\
\hline $\mathrm{NaCl}$ & 95.0 & 58.44 & 5551.8 & 5.5518 \\
\hline $\mathrm{KCl}$ & 2.50 & 74.56 & 186.4 & 0.1864 \\
\hline $\mathrm{KH} 2 \mathrm{PO}_{4}$ & 0.35 & 136.09 & 47.6315 & 0.0476 \\
\hline $\mathrm{MgSO}_{4} 7 \mathrm{H}_{2} \mathrm{O}$ & 0.2 & 246.48 & 49.296 & 0.04929 \\
\hline $\mathrm{CaCl}_{2} 2 \mathrm{H}_{2} \mathrm{O}$ & 1.71 & 147.01 & 251.387 & 0.25138 \\
\hline $\mathrm{NaHCO}_{3}$ & 25.0 & 84.01 & 2100.25 & 2.100 \\
\hline Lactate $-\mathrm{Na}$ & 10.0 & 112.1 & 1121.0 & 1.121 \\
\hline Glucose & 0.2 & 180.16 & 36.032 & 0.0360 \\
\hline pyruvate & 0.2 & 110.00 & 22.00 & 0.022 \\
\hline glutamine & 1.0 & 146.1 & 146.1 & 0.1461 \\
\hline EDTA & 0.1 & 372.24 & 37.224 & 0.0372 \\
\hline BSA & & & 4000 & 4.0 \\
\hline Penicillin & & & & 0.06 \\
\hline Streptomycin & & & & 0.05 \\
\hline
\end{tabular}

Table2. Stock A X10

\begin{tabular}{|l|l|l|}
\hline Component & mM & g/ 100ml \\
\hline $\mathrm{NaCl}$ & 95.0 & 5.5518 \\
\hline $\mathrm{KCl}$ & 25 & 0.1864 \\
\hline $\mathrm{KH}_{2} \mathrm{PO}_{4}$ & 3.5 & 0.0476 \\
\hline $\mathrm{MgSO}_{4} 7 \mathrm{H}_{2} \mathrm{O}$ & 2 & 0.04929 \\
\hline $\mathrm{CaCl}_{2} 2 \mathrm{H}_{2} \mathrm{O}$ & 1.71 & 0.25138 \\
\hline $\mathrm{Phenol} \mathrm{red}$ & & $100 \mu \mathrm{l}$ \\
\hline
\end{tabular}

Keep at $4^{\circ} \mathrm{C}$ for one month 
Table3. Stock $\mathrm{B} \%$ isotonic $\mathrm{NaHCO}_{3}$

\begin{tabular}{|l|l|}
\hline Component & $/ \mathbf{1 0 0} \mathbf{~ m l}$ \\
\hline $\mathrm{NaHCO}_{3}$ & $1.3 \mathrm{~g}$ \\
\hline Phenol Red $(0.5 \%)$ & $100 \mu \mathrm{l}$ \\
\hline
\end{tabular}

Keep at $4^{\circ} \mathrm{C}$ for one month

Percent isotonic solution from any compound is calculated by the following formula: $\%$ isotonic $=$ $0.03 \mathrm{X}$ molecular weight/ Number of ions per compound

e.g. an isotonic solution from $\mathrm{NaHCO}_{3}$

$$
\begin{aligned}
& =0.03 \times 84.03 / 2 \\
= & 1.3 \mathrm{gm} / 100 \mathrm{ml}
\end{aligned}
$$

Therefore $100 \mathrm{ml}=1.3 \mathrm{gm} \mathrm{NaHCO} 3$.

$1 \mathrm{ml}=1.3 / 100=0.013 \mathrm{gm}$

$16.2 \mathrm{ml}=0.013 \times 16.2=0.2106 \mathrm{gm} \mathrm{HCO}_{3}(210.6 \mathrm{mg} / 100 \mathrm{ml})$.

\section{Pyruvate stock X 100}

$110 \mathrm{mg} / 10 \mathrm{ml}$ in TALP, keep at $4^{\circ} \mathrm{C}$ for one week

( $2 \mu \mathrm{l} / \mathrm{ml}$ working medium)

\section{Glucose stockX 100}

$180.16 \mathrm{mg} / 10 \mathrm{ml}$ in DW, keep at $4^{\circ} \mathrm{C}$ for one week, $(2 \mu \mathrm{l} / \mathrm{ml}$ working medium).

\section{EDTA stock X1000}

$37.224 \mathrm{mg} / \mathrm{ml}$ in DW, keep at $4^{\circ} \mathrm{C}$ for one month $(1 \mu \mathrm{l} / \mathrm{ml}$ working medium).

\section{Glutamine stock X 100}

$146.1 \mathrm{mg} / 10 \mathrm{ml}$ in TALP, $(10 \mu \mathrm{l} / \mathrm{ml}$ working medium $)$

Penicillin Stock: $60 \mathrm{mg} / \mathrm{ml}$ normal saline, $(100 \mu \mathrm{l})$.

Streptomycin stock: $50 \mathrm{mg} / \mathrm{ml}$ normal saline $(100 \mu \mathrm{l})$.

Table3. Working KSOM Medium

\begin{tabular}{|l|l|l|}
\hline Component & $\mathbf{m M}$ & $/ \mathbf{1 0 0} \mathbf{~ m l}$ \\
\hline stock A & & $10 \mathrm{ml}$ \\
\hline stock B & & $16.2 \mathrm{ml}$ \\
\hline Lactate Na & & $142.6 \mu 1$ \\
\hline Glucose & 10.0 & $3.603 \mathrm{mg}$ \\
\hline pyruvate Na & 0.2 & $2.2 \mathrm{mg}$ \\
\hline L glutamine & 0.2 & $14.6 \mathrm{mg}$ \\
\hline EDTA & 1.0 & $3.72 \mathrm{mg}$ \\
\hline BSA & 0.1 & $400 \mathrm{mg}$ \\
\hline Gentamycin & & $100 \mu \mathrm{l}$ \\
\hline Streptomycin & & $100 \mu \mathrm{l}$ \\
\hline BSA & & $400 \mathrm{mg}$ \\
\hline
\end{tabular}

Filtrate and keep at $4^{\circ} \mathrm{C}$ for one week

$* 60 \%$ solution density $1.31 \mathrm{~g} / \mathrm{ml}$

\section{In Vitro Production of Mouse Embryos}

\subsection{In Vitro Maturation of Mouse Oocytes}

Plentiful numbers of oocytes can be obtained from immature (21-23 days old) female mice treated with $5 \mathrm{IU}$ of equine chorionic gonadotropin and sacrificed $48 \mathrm{~h}$ later by cervical dislocation. The ovaries are collected into a 35-mm plastic dish containing $2.5 \mathrm{ml}$ of Leibovitz L-15 medium under paraffin mineral oil to prevent evaporation of the medium. The medium is supplemented with 4 $\mathrm{mg} / \mathrm{ml}$ of bovine serum albumin (to prevent stuck of oocytes to the petri dish) and $50 \mu \mathrm{g} / \mathrm{ml}$ of 
gentamicin sulfate. Cumulus-oocyte-complexes (COCs) are released from large antral follicles using a 25-G needle. Only oocytes completely enclosed by cumulus cells are selected. COCs with dark, shrunken or irregular-shaped oocytes are discarded. About 25 COCs are transferred to a $50 \mu$ droplet of maturation medium and incubated for 15 to $17 \mathrm{~h}$ at $37^{\circ} \mathrm{C}$ in a humidified atmosphere of $5 \% \mathrm{CO}_{2}$ in air or $5 \% \mathrm{CO}_{2}, 5 \% \mathrm{O}_{2}$ and $90 \% \mathrm{~N}_{2}$. The maturation medium is Way mouth medium supplemented with $1 \mathrm{IU} / \mathrm{ml}$ of porcine follicle stimulating hormone, $10 \mathrm{ng} / \mathrm{ml}$ of human recombinant epidermal growth factor, $5 \%$ fetal calf serum, $0.23 \mathrm{mM}$ sodium pyruvate and $50 \mu \mathrm{g} / \mathrm{ml}$ of gentamicin sulfate. In vivo matured oocytes can also be collected from an immature (21 to 23 days old) female mice treated with $5 \mathrm{IU}$ of equine chorionic gonadotropin and $5 \mathrm{IU}$ of human chorionic gonadotropin (hCG) given $48 \mathrm{~h}$ apart. The mice are sacrificed by cervical dislocation between 12 and $17 \mathrm{~h}$ after the hCG treatment and the oviducts are removed and transferred to plastic dishes containing $0.4 \mathrm{ml}$ of modified KrebsRinger bicarbonate solution, TYH (5) under paraffin oil. In vivo ovulated oocytes are released from the ampullae of oviducts under the paraffin oil and guided to the droplet of TYH medium.

\subsection{In Vitro Fertilization of Mouse Oocytes}

After IVM, oocytes surrounded by the cumulus cells are subjected to IVF. Spermatozoa collected from the caudal epididymis of matured (3-6 mo old) male mice are incubated in a humidified atmosphere under paraffin oil at $37^{\circ} \mathrm{C}$ for $1 \mathrm{~h}$ in a $0.4 \mathrm{ml}$ droplet of TYH solution [5]. The droplet is supplemented with $10 \mu \mathrm{g} / \mathrm{ml}$ heparin for sperm capacitation. An aliquot of sperm suspension is added to a droplet of $0.4 \mathrm{ml}$ of TYH medium containing about 25 COCs to give a final sperm concentration of $1.5 \times 10^{5}$ cells $/ \mathrm{ml}$. Dishes are then incubated at $37^{\circ} \mathrm{C}$ for $5 \mathrm{~h}$ under $5 \% \mathrm{CO}_{2}$ in air or $5 \% \mathrm{CO}_{2}, 5 \%$ $\mathrm{O}_{2}$ and $90 \% \mathrm{~N}_{2}$.

\subsection{In Vitro Culture and Evaluation of Embryonic Development}

After IVF, presumptive zygotes are freed from cumulus cells and transferred to a $25 \mu$ droplet of potassium simplex optimized medium, $\mathrm{KSOM} \mathrm{[4]} \mathrm{and} \mathrm{cultured} \mathrm{in} \mathrm{vitro} \mathrm{at} 37^{\circ} \mathrm{C}$ in a humidified atmosphere of $5 \% \mathrm{CO}_{2}$ in air or $5 \% \mathrm{CO}_{2}, 5 \% \mathrm{O}_{2}$ and $90 \% \mathrm{~N}_{2}$. Cleavage and development to the blastocyst stage are determined at 24 and $120 \mathrm{~h}$ after IVF, respectively.

\section{IN VITRO PRODUCTION OF BOVINE EMBRYOS}

Heifers are born with all the eggs (hundred thousand oocytes) they will ever have. Unlike bulls that make new sperm daily after puberty, heifers do not make new eggs. However, these eggs will start to develop and grow in waves as puberty approaches and continue for the rest of her life. A mature fertilizable egg is only released every 18-23 days just after the heifer is in heat and as such the cow release not more than 200 mature oocytes during its entire reproductive life. Because most cows are slaughtered with hundreds of oocytes still in their ovaries, these potential genetic reserves are collected from abattoir materials by aspiration, dissection or cutting of the ovaries. Fully-grown oocytes removed from the follicles are subjected to IVM and IVF for routine embryo production.

\subsection{Oocyte Collection and Maturation of Bovine Oocytes}

Ovaries from slaughtered cows are collected at abattoir in normal saline at $37^{\circ} \mathrm{C}$ and brought to the laboratory within $5 \mathrm{~h}$ after slaughter. Oocytes are collected by aspiration from large $(1-8 \mathrm{~mm})$ follicles using a 25-G needle. Only oocytes completely surrounded by compact cumulus cells are selected and washed in modified Tyrode's medium supplemented with albumin, lactate and pyruvate, TALP [6]. Groups of up to 20 oocytes are transferred in $100 \mu$ d droplets of maturation medium (TCM 199 containing $10 \%$ heat treated fetal calf serum, $1 \mu \mathrm{g} / \mathrm{ml}$ estradiol, $5 \mu \mathrm{g} / \mathrm{ml}$ porcine luteinizing hormone and $5 \mu \mathrm{g} / \mathrm{ml}$ porcine follicle-stimulating hormone) under mineral oil into $60 \mathrm{~mm}$ petri dishes. The oocytes are incubated for $24 \mathrm{~h}$ under $5 \% \mathrm{CO}_{2}$ in air or $5 \% \mathrm{CO}_{2}, 5 \% \mathrm{O}_{2}$ and $90 \% \mathrm{~N}_{2}$ at $37^{\circ} \mathrm{C}$.

\subsection{In Vitro Fertilization of Bovine Oocytes}

Mature oocytes are washed in TALP and groups of 10 are transferred to $50 \mu 1$ droplets of fertilization medium (TALP containing $10 \mu \mathrm{g} / \mathrm{ml}$ heparin) under oil. Spermatozoa were selected by centrifugation of thawed semen on a Percol discontinuous density gradient $(45 / 90 \%)$ for $30 \mathrm{~min}$ at $700 \mathrm{~g}$. Spermatozoa are counted in a haemocytometer and diluted in the appropriate volume of TALP. Two microliters of the suspension is added to each fertilization droplet to give a final concentration of $1 \mathrm{X} 10^{6} / \mathrm{ml}$ spermatozoa. Dishes are then incubated for $18 \mathrm{~h}$ under $5 \% \mathrm{CO}_{2}$ in air at $39^{\circ} \mathrm{C}$. 


\subsection{In Vitro Culture of Bovine Embryo}

Fertilized ova are washed in culture medium (TCM 199 supplemented with 10\% heat-treated fetal calf serum). Cumulus cells are removed by repeated pipetting and the embryos are cultured in $10 \mu 1$ droplets of conditioned medium under mineral oil. The number of expanded blastocysts is determined on day seven of culture.

\subsection{In Vitro Culture of Preantral Follicles}

Current methods for IVP of embryos are dependent upon the supply of oocytes from antral or preovulatory follicles, which are present in the ovary in a relatively small number. The ovaries contain a large number of preantral follicles, which could be a potential source of fertile oocytes.So, the culture of preantral follicles for in vitro growth (IVG) has the potential to produce large quantities of oocytes for IVP and also for investigating the physiology of follicular development and ovulation in the absence of systemic influences. Different culture systems have been developed for mouse preantral follicles [7;8]. Intact preantral follicles isolated by mechanical microdissection, using a 25$\mathrm{G}$ needle, maintain the three-dimensional structure of follicles when cultured in vitro. Enzymatically isolated preantral follicles produces many fertile oocytes, but the enzymatic treatment removes the thecal cells and perforates the basal membrane so that an antrum will not form [9].

\subsection{Sperm Sexing}

The technology for sexing sperm has not changed greatly in the past twenty years, but refinements have speeded up the process and reduced damage to sperm[10]. The basic principles for sexing of spermatozoa are simple; the X-sperm contain more DNA than the Y-sperm (approximately 4\% more).The DNA content of sperm is determined using Hoechst 33342 fluorescing dye that readily penetrates the sperm cell membrane and binds to the DNA stoichiometrically. Thus, X-sperm ends up with about $4 \%$ more dye bound to their DNA than Y-sperm. The fluorescence is measured by a detector and analyzed by computer. The basic instrument used is a flow cytometer-cell sorter consists of a pump to move the fluid containing sperm past a detector of fluorescence. A laser provides the correct wavelength of light to cause fluorescence without damaging the DNA. A powerful computer also is needed to analyze the fluorescence. When the stream of fluid exits the flow cytometer, it is broken into little droplets by a vibrator, forming about 70,000 to 80,000 droplets per second. About one-third of the droplets contain a sperm and about two-thirds are empty; a few droplets contain two or more sperm. If a droplet contains an X-sperm as analyzed by the computer, a positive electrical charge is added to the droplet; if the droplet contains a Y-sperm, a negative charge is added; and if the droplet contains no sperm, multiple sperm, damaged sperm, or sperm that are indistinguishable relative to DNA content, no charge is placed on the droplet. As the droplets fall when they exit the nozzle of the flow cytometer (at a speed of about $80 \mathrm{~km} / \mathrm{h}$ ), they pass through electric fields that are positive on one side and negative on the other. Since opposite electrical charges attract each other, the droplets with a positive charge (containing $\mathrm{X}$-sperm) move toward the negative part of the field, those with a negative charge move toward the positive field, and those with no charge continue straight down. Thus, three streams of droplets are produced that can be collected into three test tubes, thereby separating the X from the Y-sperm. In practice, about $20 \%$ of sperm end up in the X-fraction, $20 \%$ in the Y-fraction and $60 \%$ are damaged or not sexable for one reason or another[11].Separation of the Xbearing chromosome from Y-bearing chromosome is an important target in animal breeding. The technology for sexing sperm can increase selection intensity, accelerate genetic improvement and generate new strategies such as breeding of unisex herd for meat production.

\section{INTRACYTOPLASMIC SPERM INJECTION}

Intracytoplasmic sperm injection (ICSI) is an in vitro fertilization (IVF) procedure in which a single sperm is injected directly into an egg. This procedure is most commonly used to overcome male infertility [12].The ICSI procedure has about the same success rate, approximately $70 \%$, as IVF in cases of non-male infertility [13]. The manipulator for ICSI procedure consists of inverted microscope and injectors. The microscope has to be equipped with a heated stage and correct optics. The correct settings and use of this equipment influence the injection procedure and may influence the success rate. Carefully prepared micro-needles with the appropriate features and the correct positioning of these needles on the inverted microscope are required for an easy injection procedure. Such technical aspects are important but are in turn valueless if the operator does not have the skill necessary to perform a proper injection. A small amount of washed and prepared sperm is placed into thick viscous 
media containing polyvinyl pyridine (PVP) in a dish. The PVP slows the sperm down so that they can be selected according to their shape, motility and trajectory. The most normal looking sperm are selected and then immobilized by squashing their tails with a glass injection needle. The sperm are sucked into the needle tail-first ready to be injected. Once ready, the egg is then placed under a microscope and moved using micromanipulation devices. A holding pipette secures the mature oocyte and then a thin, sharp glass micropipette, loaded with a single sperm, pushes first through the zonapellucida and then the oolemma. After the ICSI procedure, the oocyte is placed into the incubator and checked the following day for signs of fertilization.

\section{SPlitting of Embryo}

Splitting of embryos technique is an artificial induction of early preimplantation embryos to simulate the natural formation of identical twins. Dozens of procedures for embryos bisection have been published. Most of these procedures consist of two stages: Immobilizing the embryo by means of suction using a micropipette and bisecting the embryo with a fragment of razor blade. After removing one half of the bisected embryo an algae substance similar to the zonapellucida is added to the daughter demi-embryo. Embryo splitting at the 6-8 cell stage provided a much higher developmental efficiency compared to splitting at the 2-4 cell stage [14]. However, it is not preferable to bisect after 8-cell stage, because after this stage blastomeres start to differentiate into specialized cells. In farm animals, embryo splitting has successfully been established for several livestock species. In sheep, $36 \%$ of embryos split as 2- and 4-cell embryos developed to term following transfer to recipient females [15]. In cattle, embryos split into blastomeres at the 4-cell stage could further develop to term giving rise to multiple monozygotic healthy calves [16].Splitting of embryo provides cheap identical twins for embryo sexing, detection of genetic abnormalities and genetic marker-based selection of embryos. Human embryo splitting has been reported recently [17]. However, the complex ethical, spiritual and legislative concerns should be closely observed when dealing with human embryo splitting [14].

\section{Chimera}

In antiquity, chimera is a monster with human body and a beast head. In embryology, chimera refers to a combination of cells from different individuals. The typical method for the creation of chimera is by amalgamating a preimplantation embryo from one species with another from different species like that between a sheep and a goat [18] or between a wild and a domestic mouse [19]. The subsequent embryonic development of the aggregated embryos depend on the trophoblastic tissue which should be similar to the foster mother to lessen the rejection risk. For example when inserting a goat 8-cell stage embryo into a sheep 8-cell stage embryo or when injecting few goat embryonic cells into a sheep blastocyst, the constructed embryos should be transferred into a sheep foster otherwise the embryo will be rejected. Interspecies chimeras has been accomplished in the rat [20], rabbit [21], sheep [22] and many other mammalian species.

\subsection{Human Chimera}

Recent technological progress accomplished in the field of chimera research could now allow the production of human organs in animals and thus the generation of human-animal chimeras. Because of the dramatic organ shortage for transplantation, the medical needs for such a transgressive practice are indisputable [23; 24]. Non-human primates would be the ideal for creation of human xenotransplants, because they are genetically closer to humans. Chimpanzees are human's closest genetic kin, sharing more than ninety-nine percent of their genome. Unfortunately, Chimpanzees are endangered species and they are too few to be used for creation of human chimera. Other than Chimpanzees, the next closest species to human are baboon and pigs. However, monkeys and apes have long gestation periods and few off spring, they would not supply enough organs to significantly reduce the shortages. Furthermore, using baboons raises the risk of transmitting human pathogens. Pigs, on the other hand, have hearts that are strikingly similar to that of humans, generally healthier than most primates, extremely easy to breed, producing a whole litter of piglets at a time with a short life-cycle. However, there are serious technical barriers and complex ethical issues that must be discussed and solved before producing human organs in animals. The main ethical issues are the risks of consciousness and of human features in the chimeric animal due to a too high contribution of human cells to the brain or to the limbs [24]. Another critical point concerns the production of human gametes by such chimeric animals [25]. 
Technically, the production of human organs in animals started after the discovery of pluripotent stem cells (PSC). Such cells can differentiate into any cell types of the organism, for instance skin, liver, or pancreatic cells. Pluripotency is a key property of very specific embryonic cells found in the inner cell mass (ICM) of the early embryo and that can be derived in vitro into lines of embryonic stem cells (ESC). Another source of PSC are the induced pluripotent stem cells (iPSC) that result from reprogramming adult differentiated cells. The possibility for production of pluripotent cells from adult cells and not from ICM has many medical and scientific applications. For example, it would be possible to produce autologous medicinal cells for regenerative medicine, or to derivei PSC from patients with a genetic disease to model the disease in vitro. In 2012 Shinya Yamanaka, who invented induced pluripotent stem technology, was awarded the Nobel Prize in Medicine. For production of human xenotransplants, the carrier animal would be altered genetically in order to block the development of a certain organ, for instance the liver. Human iPSC of a patient (with liver disease) would then be injected into blastocysts obtained from such genetically knock-out animal. Thus, only human cells would contribute to the development of the liver in the carrier animal [26].The liver would then be transplanted into the patient with minimum risk of rejection.

\section{Parthenogenesis}

Parthenogenesis is a reproduction strategy common in some jawed vertebrate species, in which no sperm is involved to trigger embryonic development from the oocyte and the female generates an offspring with no paternal inheritance. Most reptiles reproduce sexually, but parthenogenesis has been observed to occur naturally in certain species of whiptails, geckos, rock lizards, blind snakes and Komodo dragons. Parthenogenesis has been studied extensively in the New Mexico whiptail of which 15 species reproduce exclusively by parthenogenesis. Recently, the Komodo dragon, which normally reproduces sexually, was found also to be able to reproduce asexually by parthenogenesis [27]. Komodo have a curious twist in their sex determination. Despite the normal mode of females being $X X$ and males as being XY, it is the other way around in these giant lizards. The genetics of sex determination in Komodo Dragons uses the ZW system (where ZW is female, ZZ is male). Parthenogenesis leads to embryos that are either ZW females or WW (unviable), with no ZZ (male) being born. An interesting aspect to reproduction in these asexual lizards is that mating behaviors are still seen, although the populations are all females. One female plays role of the male in closely related species, and mounts the female that is about to lay eggs. This behavior is due to the hormonal cycles of the females, which cause them to behave like males shortly after laying eggs, when levels of progesterone are high, and to take the female role in mating before laying eggs, when estrogen dominates. So, although the populations lack males, they still require sexual behavioral stimuli for maximum reproductive success.

\subsection{Artificial Parthenogenesis in Mammals}

In mammals, parthenogenesis is not a natural form of reproduction, as the birth of an offspring is considered not possible. However, if the oocytes of some mammals are subjected to certain stimuli they start to cleave and develop into embryos in what is known as artificial activation. It is known that, a mammalian oocyte enters the first meiotic division during embryonic life and be arrested in this phase for an extended time. Upon resumption of the first meiotic division, the oocyte is subsequently arrested at the second metaphase (MII) and becomes a haploid (with 1n chromosome number) and waits for fertilization [28]. Upon fertilization, spermatozoa overcome the second meiotic arrest by inducing a series of cellular events within the oocyte that are essential for normal development, and are collectively called oocyte activation [29]. These events include an early inter cellular rise in calcium concentration from endoplasmic reticulum stores. The induced calcium oscillation leads to resumption of meiosis, decondensation of sperm nucleus, maternal RNA recruitment, formation of male and female pronuclei, initiation of DNA synthesis, and cleavage [28].So, for induction of the parthenogenesis three main events must be induced, which occurs during normal sexual reproduction: Artificial stimulation of the oocyte, provision of a set to complete the binary number of chromosomes (2n) and the central body and strings of spindles for division and cleavage. Artificial activation of oocytes can be established using mechanical, electrical, or chemical stimuli. Probably, the second polar body rebound into the oolemma of the parthenogeneticaly activated oocytes to provide both the second set of chromosomes and also spindles for cleavage. This explains why the embryos resulting from parthenogenesis in lizards are always female, because eggs contain sexual chromosome $\mathrm{Z}$ only. 


\subsection{Artificial Parthenogenesis in Human}

Parthenogenetic activation of human oocytes obtained from infertility treatment centers have gained new interest in recent years as an alternative approach to create embryos for research in areas such as ART, somatic cell, and nuclear transfer and for derivation of clinical grade pluripotent embryonic stem cells for regenerative medicine. Experiments involving parthenogenetic embryos circumvents the ethical and legal problems concerning the use of human embryos generated for reproductive purposes. Parthenotes may be employed indifferent research areas related to ART, basic science of regulatory mechanisms and cloning experiments using somatic cell or nuclear transfer. Furthermore, the creation of parthenogenetic human pluripotent embryonic stem cell (hpESC) lines have the potential to benefit a considerable large number of patients, when used in cell therapies [30]. Differentiated cell types derived in vitro by parthenogenesis eliminate the requirement to produce or disaggregate a normal, competent embryo and may circumvent the ethical concerns voiced by some, positively impacting the debate in stem cell research [31].

\section{Conclusion}

In vitro production (IVP) of embryos provides considerable economic and scientific advantages because of the possibilities for mass production of embryos and application of the related emerging biotechnologies. Conventional IVP of embryos depends on the supply of oocytes from antral or preovulatory follicles for IVM and IVF. The culture of preantral follicles for IVG will allow exploitation of the large number of follicular oocytes in mammalian ovaries. Improvements in culture media have significantly contributed to the overall success rates of IVP. Recent advances in stem cells and gene engineering have paved the way for the generation of iESCs and hPESCs. These novel cells have gained new interest in recent years as an alternative approach to circumvent ethics and create embryos for research in areas such as xenotransplants and therapeutic medicine.

\section{REFERENCES}

[1] Chronopoulou, E. and Harper, J.C. (2015) IVF culture media: past, present and future. Hum. Reprod. Update, 21(1), 39-55.

[2] Quinn, P. (2004) The development and impact of culture media for assisted reproductive technologies. Fertil.Steril., 81, 27-29.

[3] Ringer, S. (1882) Concerning the Influence exerted by each of the Constituents of the Blood on the Contraction of the Ventricle. J.Physiol., 3,380-393.

[4] Erbach, G.T., Lawitts, J.A., Papaionnous, V.E. and Biggers, J.D. (1994) Differential growth of mouse preimplantation embryo in chemically defined media. Biol.Reprod., 50, 1027- 1033.

[5] Toyoda, Y., Yokoyama. M. andHosi, T. (1971) Studies on the fertilization of mouse eggs invitro 1: in vitro fertilization of eggs by fresh epididymal sperms. Jpn. J. Anim.Reprod.,16, 147-151 (In Japanese).

[6] Parrish,J.J., Susko-Parrish, J.L., Leibfried- Rutledge, M.L., Crister, E.S., Eyestone, W.H. and First, N.L. (1986) Bovine in vitro fertilization with frozen thawed semen. Theriogenology, 25, 591- 600.

[7] Nayudum, P.L., Fehrenbach,A., Kiesel, P., Vitt,U.A., Pancharanta, K.and Osborn, S. (2001) Progress toward understanding follicle development in vitro: appearances are not deceiving. Arch.Med.Res., 32, 587-594.

[8] Cortvrindt, R., Smitz, J. and Van Steirteghemm, A.C. (2001) In-vitro maturation, fertilization and embryo development of immature oocytes from early preantral follicles from prepuberal mice in a simplified culture system. Hum. Reprod., 11, 2656-2666.

[9] Eppigm J.J. and Schroeder, A.C. (1989) Capacity of mouse oocytes from preantral follicles to undergo embryogenesis and development to live young after growth, maturation and fertilization in vitro. Biol. Reprod., 41, 268-276.

[10] Garner, D.L. and SeidlJr, G.E. (2003) Past, present and future perspectives on sexing sperm. Can. J.Anim. Sci., 83,375-384.

[11] Seidel Je, G.E. (2007) Overview of sexing sperm. Theriogenology, 68, 443-446.

[12] De Vos, A. (2000) Intracytoplasmic sperm injection (ICSI). Hum. Reprod., 15, (Suppl. 4), 59-64.

[13] Nasr-Esfahani, M.H., Deemeh, M.R. and Tavalaee, M. (1010) artificial oocyte activation and intrcytoplasmic sperm injection. Fertil. Steril., 94(2), 520-526. 
[14] Illmesee, K., Kaskar, K. and Aavos, P. (2005) Efficient blastomere biopsy for mouse embryospkitting for future application in human assisted reproduction. Reprod. BioMed., 11, 716-725.

[15] Willadsenm S.M. (1980) the viability of early cleavage stages containing half the normal number of blastomeres in the sheep. J.Reprod. Fertil., 59, 57-62.

[16] Johnson, W.H., Loskutoff, N.M., Plante, Y. and Betteridge, K.J. (1995) Production of four identical calves by the separation of blastomeres from an in vitro derived four-cell embryo. Vet.Records, 137, 15-6.

[17] Illmesee, K. and Levanduskim, M.(2010) Embryo splitting. Mid. East Fertil. Soc. J.,15, 57-63.

[18] Fehilly, C.B., Willadsen, S.M. and Trucker, E.M.(1984) Interspecific chimaerism between sheep and goat. Nature, 307, $634-636$.

[19] Vogel, G. (2007) A knock out award in medicine. Science, 318, 178-179.

[20] Mayer,J.F.Jr., Fritz, H.I. (1974) The culture of preimplantation rat embryos and the production of allophenic rats. J. Reprod. Fertil., 39, 1-9.

[21] Gardner, R.L. and Munro, A.J. (1974) Successful construction of chimeric rabbit. Nature, 250,146-147.

[22] Tucker, E.M., Moor, R.M., and Rowson,L.E. 1974) Tetraparental sheep chimaeras induced by blastomere transplantation. Changes in blood type with age. Immunology,26, 613-621.

[23] Abouna, G.M. (2008) Organ shortage crisis: problems and possible solutions. Transplant .Proc., $40,34-8$.

[24] Bourret, R., Martinez, E., Vialla, F., Giquel1, C., Thonnat-Marin, A., De Vos, J. (2016) Humananimal chimeras: ethical issues about farming chimeric animals bearing human organs. Stem Cell Res. Therap., 7, 87.

[25] Greely, H.T., Cho, M.K., Hoge, L.F. and Satz, D.M. (2007) Thinking about the human neuron mouse. Amer. J.Bioth., 7:27-40.

[26] Rashid, T., Kobayashi, T. and Nakauchim, H. (2014) Revisiting the Flight of Icarus: making human organs from PSCs with large animal chimeras. Stem Cell, 15, 406 -9.

[27] Watts, P.C., Buley, K.R., Sanderson, S., Boardman, W., Ciofi, C. and Gibson, R.(2006) Parthenogenesis in Komodo dragons. Nature, 444, 1021.

[28] Mai, Q., Yu, Y., Li, T. (2007) Derivation of human embryonic stem cell lines from parthenogenetic blastocysts. Cell Res.17 (12), 1008-1019.

[29] Revazova, E.S., Turovets, N.A., Kochetkova, O.D. (2007) Patient specific stem cell lines derived from human parthenogenetic blastocysts. Clon. Stem Cell, 99 (3), 432-449.

[30] Bos-Mikich, A., Fabiana, F.B., Rafael, R.R., Yeda, W. and Flávio, V.M. (2015) Parthenogenesis and Human Assisted Reproduction. Stem Cells Internat., 2016,1-8.

[31] Cibelli, J.B., Grant, K.A., Chapman, K.B., Cunniff, K., Worst, T., Green, H.L., Walker, S.J., Gutin, P.H., Vilner, L., Tabar, V., Dominko, T., Kane, J., Wettstein, P.J., Lanza, R.P.,Studer, L., Vrana, K.E., West, M.D. (2002) Parthenogenetic Stem Cells in Nonhuman Primates. Science, 295, 819. 